\title{
桁橋の上部構造の崩壊と鈞合つた下部構造の設計についで
}

\author{
正員 内 田一郎**

\section{ON THE DESIGN OF THE SUBSTRUCTURE EQUILIBRATED WITH THE SUPERSTRUCTURE OF BEAM BRIDGE}

\author{
By Dr. Eng., Ichiro Uchida, C.E. Member
}

\begin{abstract}
Synopsis : The collapses of beam bridges occur at the substructure more frequently than the superstructure. One of the causes of these phenomena is the difference of the design processes of super-and substructure. In this report, at first the author examines the present design processes, and then proposes a design method which is based on the conditions that collapses of super-and substructure occur at the same time.

要 旨 桁橋の崩填は, 上部構造に特けるよりる下部構造に括いて多く起つている。その一因として 上，下部構造の設計法の相違があげられる。そこで本文に稆いてはすず従来の設計法について検討を行 い, しかるのち上, 下部構造が同時飞崩䏅するという条件飞もとづくく設計法, 特飞地船の設計支持力 をどうとつたらよいかということについて提案した。
\end{abstract}

\section{1. まえがき}

桁橋の破壤, 特飞地盤の悪いところに执いてはとの多くが下部構造に杼いて起つている。もし上部構造と下部 構造との安全度が同じにとつてあれば，上部樍造の破壊も同じ程度に生じてよいはずである。この点が現在どう なつているか，まず從来の設計について検討してみよう。しかるのち上，下部構造の安全性を同程度にするため にはどうしたらよいか，特に地盤の設計支持力をどうとつたらよいか一つの提案を示すととにする。

\section{2. 従来の設計法についての検討}

\section{(1) 上部構造に対して}

まず上部構造すなわら枌の設計法について考支てみよう。断面の大きさね一般に桁に生ずる曲げ応力によつて 決まるから，これを対象に考光ていくことにする。曲げ応力。は周知のように次の式で計算でる。

$$
\sigma=M / I y
$$

ただし $M$ : 曲げモーメント, $I$ : 断面2次モーメント, $y$ : 考光ている点の中立軸からの距離

断面の大きさはこの 0 の值が許容応力 $\sigma_{a}$ より大きくならないよろに決められるわけである。尔た許容応力 $\sigma_{a}$ は次の式で示されるすのである。

$$
\sigma_{a}=\frac{\text { 基楚強さ }}{\text { 安全率 }}
$$

基礎強さとしては, 極限強さ, 降伏点, クリープ限度, 疲れ限度などが用いられている。たとえ脆性材料で あるコンクリートなどでは極限強さが，軟鋼などでは降伏点が通常基礎強さと考光られている。ここでは一応軟 鋼のような降伏点を基礎強さとするものてついて桁の安全性について検討してみることにする。

材料の応力とひずみとの関係は実際注純に表わせるすのではないけれでも，これを図一1のように仮定す る。これは理論の奏用化を可能ならしめるため従来行つていることであ り，ここでも材料はこの図一1の応力一ヒズミ曲線を示するのとして話を 進めることにする。曲げ応力が許容曲げ応力を越觉ないということから断 面を決め大桁作用する外力を増加していくと，降伏点（図一1 に扮いて はA点) までは弾性変形を行つて，断面内の応力分布は図一2 (a)のよ うと三角形分布をなす。降伏点を越省ると縁近い部分は図一1飞したが つてヒズミの増加は応力の增加をともなわず，したがつて 図一2 (b) の ようと縁に近い部分の応力は一定值を保ち, 断面内の応力分布は台形とな
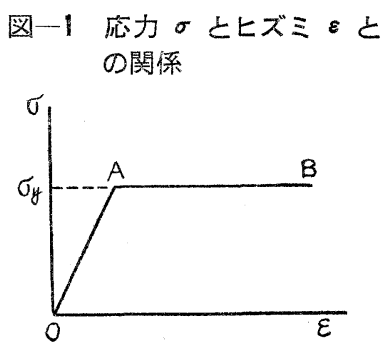
図一2 応力分布の状況

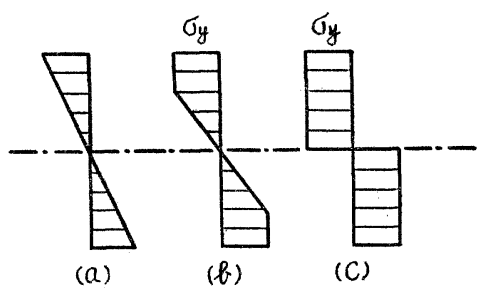

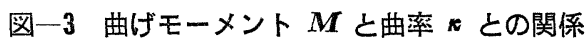

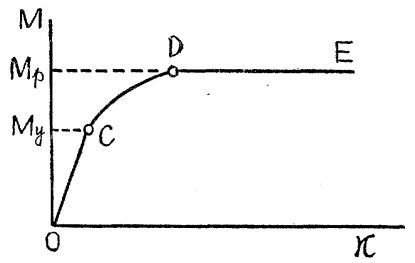

る。そして外力の増加につれて応力分布の三角形の部分は減少してきて, ついに 図-2 (c) の上うに全断面矩 形分布の状態となる。図-3 は以上の変化飞応ずるこの断面の曲げモーメントの変化を示したるのである。断面

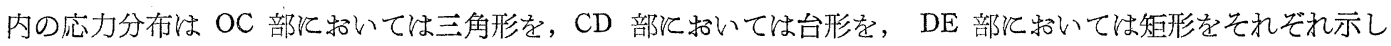
ている。また $\mathrm{C}$ 点は縁が最初に降伏点に達した時に対応, D 点は断面内すへてての点が降伏点に達した瞬間に

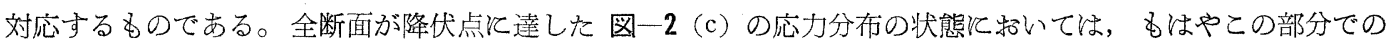
曲げモーメントは増加し得ず，いわゆる降伏ヒンジとして作用することになる。この断面の曲げモーメントを， 降伏点に和けるるのを $M_{y}$, 図一2 (c) の状態の時のすのすなわち全塑性モーメントを $M_{p}$ とすれぼ次の関係が ある1)。

\section{矩形断面の場合}

$$
M_{p}=1.5 M_{y}
$$

$I$ 形断面の場合

$$
M_{p}=1.05 \sim 1.25 M_{y}
$$

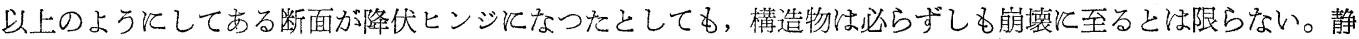
定構造物では 1 個の降伏ヒンジの出現は崩壊を意味するけれどる, 不静定構造物ではとの構造に応じて更にいく つかの降伏ヒンジが崩壊に対して必要である。

今末で述べてきたことからわかるようと，許容応力を基準にして設計した桁の断面は，設計荷重に安全率を掛 けた荷重を受けた時汇縁の応力が降伏点飞達するが, 更飞荷重の増加は可能であり, その断面の曲げモーンメト が（3）あるいは（4）式であらわせるような全塑性モーメントに達した時にはじめて降伏する。静定構造物では ここで崩壊ということになるが，不静定構造物の崩壤には更にいくつかの降伏ヒンジが必要である。

\section{(2) 下部構造に対して}

次に下部構造について考光てみよう。下部構造の設計際しては地盤の支持力, すべり出し, 転倒, 円弧すべ りなぞについて考皇なければならないが, 上部構造を経て下部構造にくる荷重の増加は一般にずり出しや転倒, 円弧すべりなどに対しては有利に働らくので，ここでは一応地盤の支持力だけを問題にしよう。上部構造と釣合 つた地盤の支持力が決まつた時にこれらのすべり出し, 転倒, 円弧すべりなぞに対しては, 地盤の支持力の持つ ベき安全度と釣合ろ安全性を持たせればよい。

下部構造を支觉る地盤はとの受ける荷重の増加忆とるなつて沈下する。その状態を示したるのが図一4である

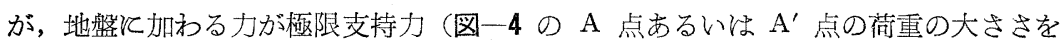
通常極限支持力と考克ている）を越觉ると下部構造は崩壊してしまう。設計の順序と してはまず設計荷重を支点に最大の反力が生ずるようと載せて，その反力を求める。 この力は橋台あるいは橋脚を経て地盤と伝えられ，この力によつて生ずる応力が極限 支持力を安全率で割つた許容支持力より小さければよいわけで, 大きくなれば杭打ち

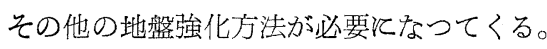

以上述べたことからわかるように上部構造は構造物の崩萝を来たさないたとえば材 料の降伏点を安全率で割つたものを基準にして設計を行つて招り，下部構造は構造物 の崩壊をもたらす地盤の極限支持力を安全率で割つたものを基準てして設計を行つて

図-4 荷重亡沈下と の関係

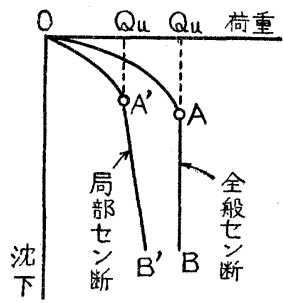
いる。上部構造と下部構造との崩壊に対する安全性が同一でないのもまた当然である。

\section{3. 提案の方法}

上部構造の設計を, 崩壊を基準として行う方法として極限設計法が最近しだいと研究されるようとなつてき た。上部構造の寸法は従来の方法あるいは極限設計法なぞで決まつているものとする。この上部構造の崩壊が起 る時に下部構造も崩壤する, そのような支点の極限支持力を求めるのがここでの目的である。この極限支持力が 決まれば，それだけの支持力を持たせるようと地盤を強化しあるいは橋台，橋脚の構造を造ればよいわけであ る。目的を達するためにここで利用する関係は次の 2 つである。 
（a）荷重がその作用点の移動炕よてなす仕事は，降伏ヒンジに招いて全塑性モーメントが変形に抵抗して なす仕事と支点飞颃いて反力が沈下飞抵抗してなす仕事との和に等しい。

（b）ヒンジあるいは降伏ヒンジではさまれているハリの部分に対して作用する力，モーメントなどは釣合つ ていなければならない。

以下いろいろな析について個々飞説明すること飞しょう。な招, 上部構造の崩壊形式は計算の際飞知ることが できるが, 支点が弱くて沈下が起つても上部構造の崩壊荷重は変わ らず22, 乙たがつて支点の沈下を同時飞考劣る場合の上部構造の崩 壞形式は上部構造だけを考觉る場合のものと同じである。また，特 そことわらない限りは断面と降伏ヒンジのできる時の全塑性モーメ ントを $M_{p}$ といろ記号であらわすこととする。

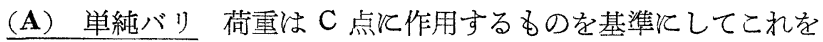
$W$ とし, 他の点と作用するすのはこの $W$ 亿係数を掛けて表わする

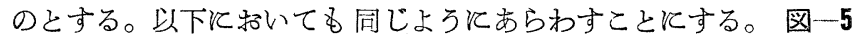
（a）飞示すような荷重を受ける場合饥て考皇てみる。W が $W_{1}$ になつた時 図一5 (b) のようにC 点で降伏ヒンジを生じて崩壊が 起つたとすれば次の式が成立する。

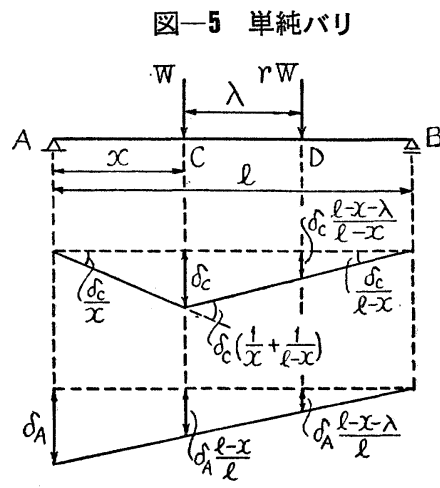

$$
W_{1} \delta_{c}+r W_{1} \delta_{c} \frac{l-x-\lambda}{l-x}=M_{p^{\circ} c}\left(\frac{1}{x}+\frac{1}{l-x}\right) \quad \therefore W_{1}=\frac{l}{x\{(l-x)(1+r)-r \lambda\}} M_{p}
$$

いま $\mathrm{A}, \mathrm{B}$ 両支点の極限支持力をとれぞれ $Q_{u A}, Q_{u B}$ とする。A 支点が沈下崩壊する時すなわち 図一5 (c) の 状態汶して，荷重 $W$ を $W_{2}$ とすれば次の式が成立する。

$$
W_{2}{ }^{\delta} A \frac{l-x}{l}+r W_{2}{ }^{\partial} \frac{l-x-\lambda}{l}=Q_{u A^{\delta} A} \quad \therefore W_{2}=\frac{l}{(l-x)(1+r)-r \lambda} Q_{u} A
$$

（b）の状態と（c）の状態とが同時に起るためには $W_{1}=W_{2}$ でなければならない。すなわち

$$
\frac{l}{x\{(l-x)(1+r)-r \lambda\}} M_{p}=\frac{l}{(l-x)(1+r)-r \lambda} Q_{u} A \quad \therefore Q_{u A}=\frac{M_{p}}{x}
$$

すなわち $Q_{u A}$ を (7) 式の值飞とれば，上部構造の崩壤と同時飞支点 $\mathrm{A}$ の崩壊 子生ずるわけである。この值恃 図一5 (b) の AC 部の崩壊時の釣合からも求める ことができ，実際恃この方が計算が簡単である。図一～亿招いて C 点関する モーメントの鈞合を考党れば

$$
Q_{u A} x-M_{p}=0 \quad \therefore Q_{u A}=M_{p} / x
$$

図一 $\quad$ A C 部の釣合

すなわち (7) 式と同じるのがでてくる。支点 B そついても全く同様に

$$
Q_{u B}=\frac{x(1+r)+r \lambda}{x\{(l-x)(1+r)-r \lambda\}} M_{p}
$$

以上の上うな值 $Q_{u A}, Q_{u B}$ の極限支持力で下部構造を設計すれば，その崩壊は上部構造と同時飞生ずる。

例：図一7 のような単純バリとついて考光てみる。許容応力 $\sigma_{a}=1300 \mathrm{~kg} / \mathrm{cm}^{2}$, 降伏点 $\sigma$ 降 $=2300 \mathrm{~kg} / \mathrm{cm}^{2}$ と する。まず通常の方法で断面の大きさを決めてみる。

最大曲げモーメント $M_{\max }=10 \mathrm{tm}=1000000 \mathrm{~kg} \cdot \mathrm{cm}$

必要な断面係数 $\quad W=\frac{M_{\mathrm{max}}}{\sigma_{a}}=\frac{1000000}{1300}=769.3 \mathrm{~cm}^{3}$

$I$ 形鋼を用いるとして, $I 300 \times 150 \times 10\left(I=12730 \mathrm{~cm}^{4}, W=848.7 \mathrm{~cm}^{3}\right)$ を採用すればよい。すると $M_{y}=\sigma_{y} W=2300 \times 848.7=1952010 \mathrm{~kg} \cdot \mathrm{cm}$

$M_{p}=1.15 M_{p}$ として $M_{p}=1.15 \times 1952010=2244812 \mathrm{~kg} \cdot \mathrm{cm}$

図一8 のように AC 部の釣合を考えて $Q_{u A}$ を求めれね゙

$$
200 Q_{u A}-M_{p}=0 \quad \therefore Q_{u A}=\frac{M_{p}}{200}=\frac{2244812}{200}=11.224 \mathrm{~kg}=11.224 \mathrm{t}
$$

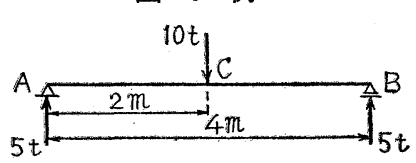

図一，A C 部の釣合

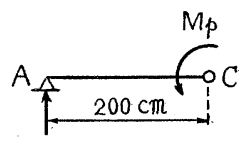

この值を極限支持力とすれば釣合うことになる。従来の方法だと，たと光ば安全率を 2 とし反力 $5 \mathrm{t}$ 亿を 掛けた $10 \mathrm{t}$ だけの極限支持力があればよいということで対策を構ずることになる。

(B) 片持バリ 図一9 亿执いて最大曲げモーメントは A 点に括いて生ずるから, ハリはこの点浲伏ヒン ジができて崩壊する。すなわち 図一9（b）のような状態となり，この時の $W$ を $W_{1}$ とすれば次の式が成立す 
る。

$$
W_{1} \delta_{c}+r W_{1} \delta_{c} \frac{x+\lambda}{x}=M_{p} \frac{\delta_{c}}{x} \quad \therefore W_{1}=\frac{M_{p}}{(1+r) x+r \lambda} .
$$

Wま支点 $\mathrm{A}$ の極限支持力（垂直方向）を $Q_{u A}$ とし，図一-9 (c) の ようにこの点が沈下崩壊したとすれば，その時の荷重 $W_{2}, r W_{2}$ そ対 して次の式が成立する。

$$
W_{2} \delta_{A}+r W_{2} \delta_{A}=Q_{u A^{\delta} \delta_{A}} \quad \therefore W_{2}=\frac{Q_{u A}}{1+r}
$$

(b), (c) の状態が同時飞起る。すなわちハリの崩壊と支点の沈下が

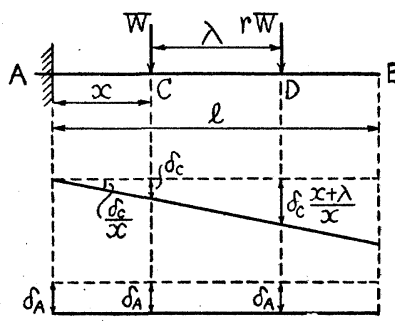
同時に起るためとは $W_{1}=W_{2}$ ならばよい。すなわち

$$
\frac{M_{p}}{(1+r) x+r \lambda}=\frac{Q_{u A}}{1+r} \quad \therefore Q_{u A}=\frac{1+r}{(1+r) x+r \lambda} M_{p}
$$

ハリが崩壊すると同時に固定端に物けるハリの回転が起るためには, 固定端の抵抗モーメントが $\mathrm{A}$ 点に括け るハリの $M_{p}$ 等しければよい。ハリが崩壊した瞬間に招ける釣合の条件から $Q_{u A}$ を求めてみる。図一10 K 呿いて A 点飞郝けるモーメントの釣合を考光ると

$$
W_{1} x+r W_{1}(x+\lambda)-M_{p}=0 \quad \therefore W_{1}=\frac{M_{p}}{(1+r) x+r \lambda}
$$

この值はもちろん（9）式等しい。 $Q_{u A}$ はこのような瞬間に持ける $W_{1}$ と $r W_{1}$ とを支持していなければならないから

$$
Q_{u A}=W_{1}+r W_{1}=\frac{1+r}{(1+r) x+r \lambda} M_{p}
$$

(11) 式と同じ值がでてくる。

(C) 一端固定，他端移動支点の八リ）ハリの崩壊は 図一11(b) のようにC 点飞和いて起るるのとすれば次の式が成立する。な特， この時の $W$ の值を $W_{1}$ とし， $M_{p}$ の值はどこそ掠いても同じとす る。

$$
\begin{aligned}
& W_{1} \delta_{c}+r W_{1} \delta_{c} \frac{l-\lambda-x}{l-x}=M_{p} \frac{\delta_{c}}{x}+M_{p} \delta_{c}\left(\frac{1}{x}+\frac{1}{l-x}\right) \\
& \therefore W_{1}=\frac{2 l-x}{x\{(l-x)(1+r)-r \lambda\}} M_{p}
\end{aligned}
$$

ハリの崩垻前に和いて $W=W_{2}$ の時に支点 $\mathrm{B}$ の沈下が起つたと すれば，図一11（c）飞执いて次の式が成立する。ただし B 支点の

図一10 AB 部の釣合

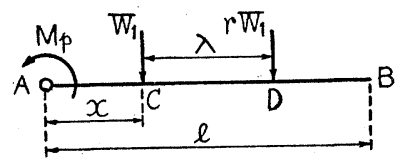
極限支持力を $Q_{u B}$ とする。

$$
W_{2} \delta_{B} \frac{x}{l}+r W_{2} \delta_{B} \frac{x+\lambda}{l}=M_{p} \frac{\delta_{B}}{l}+Q_{u B} \delta_{B} \quad \therefore W_{2}=\frac{1}{x(1+r)+r \lambda} M_{p}+\frac{l}{x(1+r)+r \lambda} Q_{u B}
$$

(b),(c) の状態が同時に起るとすれば， $W_{1}=W_{2}$ と物いて

$$
\begin{aligned}
& \frac{2 l-x}{x\{(l-x)(1+r)-r \lambda\}} M_{p}=\frac{1}{x(1+r)+r \lambda} M_{p}+\frac{l}{x(1+r)+r \lambda} Q_{u B} \\
& \therefore Q_{u B}=\frac{x(1+r)+2 r \lambda}{x\{(l-x)(1+r)-r \lambda\}} M_{p}
\end{aligned}
$$

$Q_{u B}$ がこの值をとれね゙上，下部構造が同時に崩壊することになる。

次飞 CB 部の釣合を考えて上, 下部構造の崩壊が釣合う時の $Q_{u B}$ の值を求めてみよう。ハリの最初の降伏七 ンジが C 点に生ずるとすれば，その時の $W$ は (12) 式であらわせる $W_{1}$ である。この状態で図一12のよろ 飞 CB 部の釣合を考学ると，C 点汇関するモーメントの釣合から次の式が成立する。

$$
-Q_{u B}(l-x)+r W_{1} \lambda+M_{p}=0 \quad \therefore Q_{u B}=\frac{r \lambda}{l-x} W_{1}+\frac{1}{l-x} M_{p}
$$

(12) 式の $W_{1}$ の值を入れて $Q_{u B}=\frac{x(1+r)+2 r \lambda}{x\{(l-x)(1+r)-r \lambda\}} M_{p}$

(14) 式の值を得る。

固定端である A 支点とついては次に述べる固定バリと同じようと取扱兄

図一12 CB 部の釣合

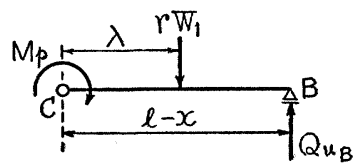


ればよい。

(D) 固定バり ハリの崩壊が 図一13（b）のようと起るもの之 すれば，次の式が成立する。な数，この時の $W$ を $W_{1}$ とする。

$$
\begin{array}{r}
W_{1} \delta_{c}+r W_{1} \delta_{c} \frac{l-\lambda-x}{l-x}=M_{p} \frac{\delta_{c}}{x}+M_{p} \delta_{c}\left(\frac{1}{x}+\frac{1}{l-x}\right)+M_{p} \frac{\delta_{c}}{l-x} \\
\therefore W_{1}=\frac{2 l}{x\{(l-x)(1+r)-r \lambda\}} M_{p} \cdots \cdots(15)
\end{array}
$$

次に A,C 両点の降伏ヒンジの発生と同時に B 点の沈下が起つ たとすれば 図一13 (c) Kより次の式が成立する。な扮，この時の $W$ を $W_{2}$ とする。

$$
\begin{aligned}
W_{2} \delta_{B}+r W_{2} \delta_{B} & =M_{p} \frac{\delta_{B}}{x}+M_{p} \frac{\delta_{B}}{x}+Q_{u B} \delta_{B} \\
\therefore W_{2} & =\frac{2}{(1+r) x} M_{p}+\frac{1}{1+r} Q_{u B}
\end{aligned}
$$

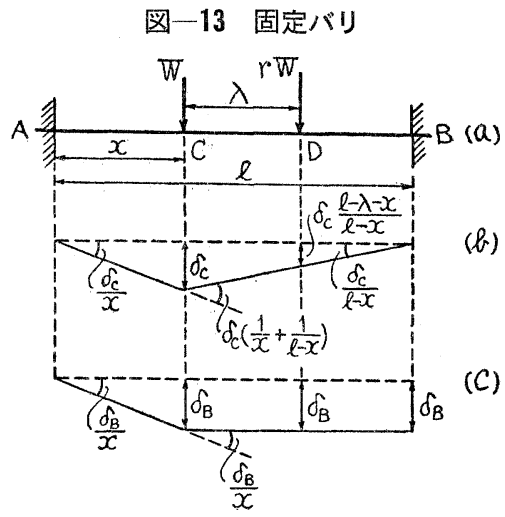

この場合 B 点の沈下注対して図一11 (c) のような形式も考兄られるが, そうすると B 点の固定モーメン トの仕事の影響を考慮する必要を生ずるので, 取扱いの便宜上から上のようと 図一13 (c) の状態で考觉た。

(b),(c) の状態が同時汇起るとすれば $W_{1}=W_{2}$ と招いて

$$
\frac{2 l}{x\{(l-x)(1+r)-r \lambda\}} M_{p}=\frac{2}{(1+r) x} M_{p}+\frac{1}{1+r} Q_{u B} \quad \therefore Q_{u B}=\frac{2(x+r x+r \lambda)}{x\{(l-x)(1+r)-r \lambda\}} M_{p} \cdots
$$

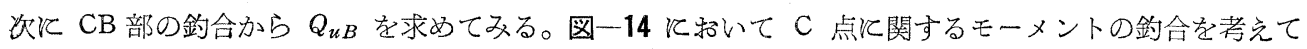

$$
\begin{gathered}
-Q_{u B}(l-x)+r W_{1} \lambda+M_{p}+M_{p}=0 \\
\therefore Q_{u B}=\frac{r \lambda}{l-x} W_{1}+\frac{2}{l-x} M_{p}
\end{gathered}
$$

(15) 式の $W_{1}$ の値を入れて $Q_{u B}=\frac{2(x+r x+r \lambda)}{x\{(l-x)(1+r)-r \lambda\}} M_{p}$ 図一14 CB 部の釣合

(17) 式と同じ值を得る。B 支点の極限支持力としてこのような值を与兄れ

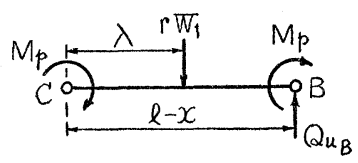

ぼ，桁と支点との崩壊が同時に起る。

な特，固定支点飞招郆る抵抗モーメントはハリの全塑性モーメント $M_{p}$ と同じ值にすれね゙よい。

(E) 連続バリ 全塑性モーメントをスパン $\mathrm{AB}$ は $M_{p_{1}}$, スパン $\mathrm{BC}$ 怯 $M_{p_{2}}$ とし, $M_{p_{1}}>M_{p_{2}}$ とする。をた $\mathrm{A}, \mathrm{B}, \mathrm{C}$ 各支点の極限支持力をとれぞれ $Q_{u A}, Q_{u B}, Q_{u C}$ とする。連続バリの場合とは局部崩㖜が普通であるが, その崩壊形式としては 図一15 (b)〜 (f) の上ろなるのが 考克られる。その各場合飞ついて崩壊荷重を求めてみる と次のと拉りである。

(b) の場合 $\left(W=W_{1}\right)$

$$
\begin{gathered}
W_{1} \delta_{D}=M_{p_{1}} \delta_{D}\left(\frac{1}{x_{1}}+\frac{1}{l_{1}-x_{1}}\right)+M_{p_{2}} \frac{\delta_{C}}{l_{1}-x_{1}} \\
\therefore W_{1}=\frac{l_{1}}{x_{1}\left(l_{1}-x_{1}\right)} M_{p_{1}}+\frac{1}{l_{1}-x_{1}} M_{p_{2}} \cdots
\end{gathered}
$$

(c) の場合 $\left(W=W_{2}\right)$

$$
\begin{gathered}
r W_{2} \delta_{E}=M_{p_{2}} \frac{\delta_{E}}{x_{2}}+M_{p_{2}} \delta_{E}\left(\frac{1}{x_{2}}+\frac{1}{l_{2}-x_{2}}\right) \\
\therefore W_{2}=\frac{2 l_{2}-x_{2}}{r x_{2}\left(l_{2}-x_{2}\right)} M_{p_{2}} \ldots \ldots \ldots \ldots \ldots \ldots
\end{gathered}
$$

(d) $の$ 場合 $\left(W=W_{3}\right)$

$$
\begin{aligned}
& W_{3} \delta_{A} \frac{l_{1}-x_{1}}{l_{1}}=M_{p_{2}} \frac{\delta_{A}}{l_{1}}+Q_{u A} \delta_{A} \\
& \therefore \mathrm{W}_{3}=\frac{1}{l_{1}-x_{1}} M_{p_{2}}+\frac{l_{1}}{l_{1}-x_{1}} Q_{u A}
\end{aligned}
$$

(e) の場合 $\left(W=W_{4}\right)$

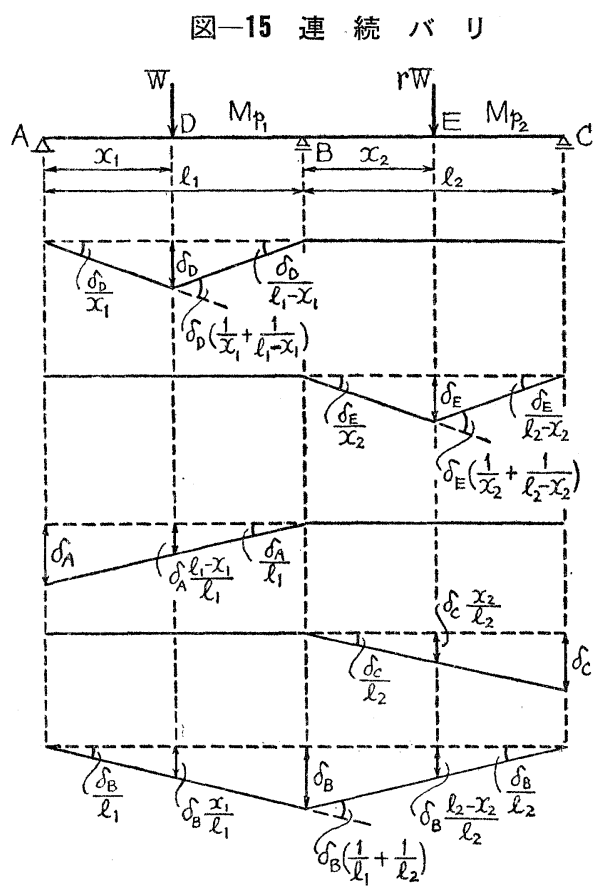




$$
\begin{gathered}
r W_{4} \delta_{c} \frac{x_{2}}{l_{2}}=M_{p_{2}} \frac{\delta_{c}}{l_{2}}+Q_{u c} \delta_{c} \\
\therefore W_{4}=\frac{1}{r x_{2}} M_{p_{2}}+\frac{l_{2}}{r x_{2}} Q_{u c}
\end{gathered}
$$

(f) の場合 $\left(W=W_{5}\right)$

$$
\begin{gathered}
W_{5} \delta_{B} \frac{x_{1}}{l_{1}}+r W_{5} \delta_{B} \frac{l_{2}-x_{2}}{l_{2}}=M_{p_{2}} \delta_{B}\left(\frac{1}{l_{1}}+\frac{1}{l_{2}}\right)+Q_{u B} \delta_{B} \\
\therefore W_{5}=\frac{l_{1}+l_{2}}{x_{1} l_{2}+r l_{1}\left(l_{2}-x_{2}\right)} M_{p_{2}}+\frac{l_{1} l_{2}}{x_{1} l_{2}+r l_{1}\left(l_{2}-x_{2}\right)} Q_{u B}
\end{gathered}
$$

以上求めたいろいろな場合を組合わせれげ次のようなととがいえる。

(i) $W_{1}=W_{2}$ となるように $M_{p_{1}}$ と $M_{p_{2}}$ との関係を定めれば，上部構造両スパンが同時に崩疃する。

(ii） $W_{1}=W_{3}$ そなるようと $Q_{u A}$ を $M_{p_{1}}$ 招よび $M_{p_{2}}$ と関係ずければ A 支点と左側スパンが同時飞崩壊す る。

(iii) $W_{2}=W_{4}$ そなるよう飞 $Q_{u C}$ を $M_{p_{2}}$ と関係ずければ C 支点と右側スパンとが同時に崩㘊する。

(iv） $W_{1}=W_{2}=W_{3}=W_{4}=W_{5}$ そなるように各スパンの全塑性モーメント，各支点の極限支持力を定めれば， もつとも鈎合のとれた設計になる。

その他の起り得る場合についても同様に䠸えればよい。

\section{4. む す び}

以上特別な例題で説明したけれでも，ぞのようなハリ，荷重の場合でも同じようと取扱うことができる。ハリ の材料あるいは地盤などの実際の性質は仮定と若干異なつているが，この点関することは将来研究しなければ ならない問題である。また地震その他のことと対する考慮も必要であるが，その取扱い方によつては提案の方法 と同じ考光方によつて処理できる場合もあるし，また更研究すべき余地も大である。

終りに, 討議を頂いた東京大学 奥村敏恵氏, 熊本大学 吉村虎蔵氏に感謝の意を表する。

\section{参 考 文 献}

1) たとえば

倉西正嗣：極限設計法, p. 17

岡本舜三：構造力学 $(V)$ 極限設計法 $(I)$, 土木学会誌 第 43 巻 第 8 号（昭 33-8） p. 45

2) 梅村 魁: 塑性ラーメンの自己歪応力と終局強度, 日本建築学会研究報告 第 31 号（第 1 部) (昭 30-5) p. 167 